\title{
Risk and price in the bidding process of contractors
}

Article

Accepted Version

Laryea, S. and Hughes, W. (2011) Risk and price in the bidding process of contractors. Journal of Construction Management and Engineering, 137 (4). pp. 248-258. ISSN 1943-7862 doi: https://doi.org/10.1061/(ASCE)CO.19437862.0000293 Available at https://centaur.reading.ac.uk/8158/

It is advisable to refer to the publisher's version if you intend to cite from the work. See Guidance on citing.

To link to this article DOI: http://dx.doi.org/10.1061/(ASCE)CO.19437862.0000293

Publisher: American Society of Civil Engineers

Publisher statement: Original paper published at: http://dx.doi.org/10.1061/ (ASCE)CO.1943-7862.0000293

All outputs in CentAUR are protected by Intellectual Property Rights law, including copyright law. Copyright and IPR is retained by the creators or other copyright holders. Terms and conditions for use of this material are defined in the End User Agreement.

www.reading.ac.uk/centaur

\section{CentAUR}


Central Archive at the University of Reading

Reading's research outputs online 


\title{
Risk and price in the bidding process of contractors
}

\author{
Samuel Laryea ${ }^{1}$ and Will Hughes ${ }^{2}$
}

\footnotetext{
${ }^{1}$ Lecturer, School of Construction Management and Engineering, University of Reading, P.O. Box 219, Reading, RG6 6AW, UK (corresponding author)

${ }^{2}$ Professor of Construction Management and Economics, School of Construction Management and Engineering, University of Reading, P.O. Box 219, Reading, RG6 6AW, UK
} 


\title{
Risk and price in the bidding process of contractors
}

\begin{abstract}
Formal and analytical risk models prescribe how risk should be incorporated in construction bids. However, the actual process of how contractors and their clients negotiate and agree on price is complex, and not clearly articulated in the literature. Using participant observation, the entire tender process was shadowed in two leading UK construction firms. This was compared to propositions in analytical models and significant differences were found. 670 hours of work observed in both firms revealed three stages of the bidding process. Bidding activities were categorized and their extent estimated as deskwork (32\%), calculations (19\%), meetings (14\%), documents $(13 \%)$, off-days $(11 \%)$, conversations $(7 \%)$, correspondence $(3 \%)$ and travel $(1 \%)$. Risk allowances of 1-2\% were priced in some bids and three tiers of risk apportionment in bids were identified. However, priced risks may sometimes be excluded from the final bidding price to enhance competitiveness. Thus, although risk apportionment affects a contractor's pricing strategy, other complex, microeconomic factors also affect price. Instead of pricing in contingencies, risk was priced mostly through contractual rather than price mechanisms, to reflect commercial imperatives. The findings explain why some assumptions underpinning analytical models may not be sustainable in practice and why what actually happens in practice is important for those who seek to model the pricing of construction bids.
\end{abstract}

Keywords: bidding, contractor, participant observation, risk apportionment, UK 


\section{Introduction}

Formal and analytical risk models that contractors can incorporate into the bidding process for the purpose of allocating risk contingencies have proliferated in recent years (for example, a fuzzy set model by Zeng et al., 2007; a fuzzy logic-based artificial neural network model by Liu and Ling, 2005; a fuzzy set model by Paek et al., 1993; a fuzzy set model by Tah et al., 1993; and an influence diagramming-based technique by Al-Bahar and Crandall, 1990). However, several empirical studies of contractors have shown that they are rarely used in practice: seven contractors in UK studied by Tah et al. (1994); 30 in UK by Akintoye and MacLeod (1997); 12 in US by Smith and Bohn (1999); 84 in UK by Akintoye and Fitzgerald (2000); 38 in Hong Kong by Wong and Hui (2006); and 60 in Hong Kong by Chan and Au (2007). As this paper will demonstrate, the relationship between risk and price in the process used by contractors to calculate their bids for construction work is not articulated sufficiently in the literature (summarized in Laryea and Hughes, 2008).

Most analytical risk models proposed by academic researchers have sought to prescribe how risk should be included in a bidding price. However, the actual process of how contractors and their clients negotiate and agree on price is complex, and not clearly illuminated in most of the literature. As explained in a construction contracts textbook by Murdoch and Hughes (2008: 128), many contracts for construction work are created by the process of tender, which often involves some form of market competition that clients use to obtain the lowest price from contractors.

The fact that the pricing of work occurs in the tender process means that first, a basic understanding is needed of the whole tender process used by contractors to arrive at a bidding price. Second, a basic understanding is needed of how, and in what circumstances, that price is influenced by the apportionment of risk. However, there is little empirical research on the whole process used by contractors to put together a bidding price (see Appendix 1). Without a precise understanding of how contractors price a bid and take account of risks in reality, it would be hard to conceptualize analytical models for approaching risk response in the way that it normally happens in practice. Clearly, risk assessment ought to have a serious influence on a contractor's pricing strategy, but other factors also affect price. 
The price clients will be willing to pay for construction work depends not only on their available resources, but also on what other sellers (contractors) in the market are willing to offer the same product for (see the elemental micro-economic theory of the behaviour of individual competitive markets in Lipsey, 1979: 93).

Thus, a bidding price may be dependent on the market or competitive environment in which it takes place. Brook (2004) explains that bidding often involves two processes. First, estimating, which is the stage is where the actual project costs are taken into account. Clearly, this process may depend on the level of expertise in a contractor's estimating department. Second, adjudication, which is the stage where the directors of a firm will take a commercial view on the estimated cost, in the context of the firm's particular circumstances, market conditions and risk. Thus, management will ultimately try to pitch the bidding price between cost and value in order to win the work (see explained in Murdoch and Hughes, 2008: 138-9).

The approach used by contractors to take account of risk in the whole process of trying to pitch their bidding price to respond to these factors is not always clearly explained in the literature (see Appendix 1). However, several analytical approaches have been proposed to help contractors in dealing with risk when bidding. Without sufficient understanding of how contractors actually price a bid and take account of risks in reality, it would be hard to conceptualize analytical models that align with what contractors actually do. But quite understandably, as authors like Skitmore and Wilcock (1994: 142) acknowledged, it is hard to get contractors to participate in studies of such nature mainly because of the commercially sensitive data involved.

Several studies of contractors have shown that contractors are often reluctant to take full account of the cost of risk in their bidding price. The main reason is to avoid inflating their price with risk allowances and become uncompetitive (see for example, an interview study of 12 US contractors by Smith and Bohn, 1999; and a questionnaire study of 400 US contractors by Mochtar and Arditi, 2001). Thus, it is unsurprising that several studies have shown that most contractors rarely approach the incorporation of risk in their bid proposals according to the contingency allocation theory prescribed by most analytical models. It also implies that there are probably other risk response mechanisms used by contractors themselves that can be learned and used to inform practical risk analysis techniques. 


\section{Background}

It is standard text-book knowledge that risk is part of business endeavors because of uncertainty (Flanagan and Norman, 1993; Fisher and Jordan, 1996). Portfolio theory and capital market theory stipulate that the total risk comprises two types of risk (see financial analysis and portfolio management textbook by Fisher and Jordan, 1996). First, systematic risk, which cannot be controlled, emanates from external factors such as Acts of God, natural disasters, market risk, interest-rate risk and purchasing power risk. Second, unsystematic risk, which can be controlled relates to organizationspecific factors such as business risk and financial risk. These forms of risk are also fundamental to the construction (internal and external risk) and the insurance (pure and speculative risk) industries (see, for example, a study on risk allocation in tenders by Tah et al., 1993; and a standard textbook on insurance by Dorfman, 2002).

As shown in a financial analysis textbook by Fisher and Jordan (1996), one way of pricing a product to meet expected profit is to quantify risk and build a required rate of return that comprises a riskless rate plus compensation for individual risk factors. Based on several years' working experience, Connolly (2006) explained that risk has cost, which can sometimes be catastrophic. However, it is not easy to predict or to price risk, as shown in a survey of the top 400 US contractors, which revealed that pricing is a complex and difficult task for entrepreneurs (Mochtar and Arditi, 2001).

According to a conceptual study by Mulholland and Christian (1999) in which an analytical approach was proposed for risk assessment in construction schedules, construction projects are initiated in complex and dynamic environments resulting in circumstances of high uncertainty and risk, which are compounded by demanding time constraints. Flanagan and Norman (1993) explained that every construction project is unique in its features and risk. However, risk is not unique to the construction sector, as explained in textbook on subjective probability by Wright and Ayton (1994). The definitive guidance on economic theory and the construction industry observed that it is more often the way a set of factors combine to affect construction work which makes the industry unique (Hillebrandt, 1985). In a historical overview of the construction industry, Hughes and Hillebrandt (2003: 508510) showed that these factors relate to the economic, contractual, political and physical environments in which construction projects take place and they tend to affect the way construction work is described, awarded, and documented. These 
factors include: necessity to price product before production, competitive tendering, low fixed-capital requirements, preliminary expenses, delays to cash-inflows, tendency to operate with too low a working capital, seasonal effects, fluctuations and their effects, Government intervention, activity related to development, uncertain ground conditions, unpredictable weather, and no performance liability or long-term guarantees. These factors are also explained in textbooks by Calvert et al. (1995) and Kwakye (1997) that also show that construction projects are mostly complex, have a long production cycle, and involve the input of many participants.

Some aspects of the construction management literature, for example Baloi and Price (2003: 262) and Ahmed et al. (2002: 4), have argued that contractors are poor at managing risk, simply because the experiential-based mechanisms they are reported to use in approaching risk are not 'systematic' in nature. However, this assertion does not ring true, in the light of other descriptions of the construction sector. A historical overview of the construction industry by Hughes and Hillebrandt (2003: 511) shows that since the early part of the $19^{\text {th }}$ century, contractors have responded to risks in construction industry using various means. Most contractors resorted to speculative house building in the $19^{\text {th }}$ and $20^{\text {th }}$ centuries to sustain labor force and business costs through the peaks and troughs of contracted work. In modern times, there is a growing tendency for contractors to use their positive cash flows to invest in projects, rather than house building. More recently, successful contractors are diversifying into businesses whose cycles counteract that of construction. Nowadays, contractors are mitigating risk by declining work perceived as too risky, subcontracting large portions of their work to others, and apportioning risk in wage structures. In essence, they are passing risk on to others in the supply chain. So, they seem adept at managing risk. However, by its very nature, risk is difficult to mitigate fully, and this applies to all business sectors, not just construction.

Construction practitioners are often trained to take account of risk in projects, particularly, for example, in the compilation of a risk register, as outlined by the Project Management Institute (2004: 237-268). This demonstrates that the importance of risk analysis is understood by practitioners. However, a detailed understanding of how contractors get from this understanding of risk to a price is not typically explained in the literature. 
The construction management literature articulates experience and intuition as the main mechanisms that contractors use for pricing risks. For example, a survey of 400 US contractors by Mochtar and Arditi (2001) showed that:

"In setting their bid offer, most contractors rely on their intuition after subjectively assessing the competition; most contractors do not use special pricing software".

However, most analytical approaches appear to argue that experience and intuition do not form an adequate professional and objective basis for serious project management decisions (for example, Al-Bahar and Crandall, 1990). More than 60 'systematic' and 'rational' approaches have been proposed as logical substitutes for the traditional, intuitive, unsystematic approach used by most contractors when it comes to dealing with risk (see Laryea and Hughes, 2008). However, in most of the studies reviewed, no reference is made to any comprehensive empirical work that explains how contractors actually take account of risk in the whole tender process.

Several authors, for example Kangari and Riggs (1989); Paek et al. (1993); Tah et al. (1993); and Liu and Ling (2005), have also proposed analytical models that contractors can use to assess risk in the bidding process. Citing the lack of significant work in construction risk analysis by fuzzy sets, Kangari and Riggs (1989) proposed a fuzzy set risk assessment methodology that can give contractors "...a more rational basis on which to make decisions". The authors showed how a risk value, calculated using fuzzy set principles, may be included as a risk premium in bids. However, no reference is made to any empirical research on what contractors actually do.

Using the same fuzzy set theory, Paek et al. (1993) proposed a risk-pricing method that contractors can use for analyzing and pricing risk when "...faced with the problem of deciding the bidding price of a construction project when the likelihood of the occurrence of risk events and the risk associated consequences are uncertain". The model prescribed how an optimum risk premium should be included in construction bids. Here too, no reference is made to any empirical research on what contractors actually do.

Tah et al. (1993) developed a conceptual model for “contractor's risk assessment during tender preparation for the purpose of allocating contingencies to cover the risks" using the principles of fuzzy set theory. Liu and Ling (2005) introduced a fuzzy logic-based artificial neural network model to help contractors in the "...estimation of 
markup in a changeable and uncertain construction environment”. In justifying the model development, Liu and Ling argued that:

“...it is important to be able to model markup estimation as the model can act as a decision aid to help contractors to overcome their shortcomings in judgment and limited short-term memory, which prevents them from processing large amounts of information".

However, the study cites no evidence to show that contractors do indeed have shortcomings in their judgment and a limited short-term memory, for which reason they require a sophisticated model to help in markup estimation.

This paper argues that the mechanisms used by contractors to price risks in the bidding process should inform practical risk analysis techniques. The way that contractors and their clients negotiate and agree on price is complex, and not well explained in most of the literature. Several experiential-based textbooks and materials on estimating and bidding were identified for example, Brook (2004); Buchan et al. (2003); Hinze (1993); Harrison (1991); Skitmore (1989); Smith (1986); Geddes (1985); Wood (1982); Enterkin and Reynolds (1978); Wainwright and Wood (1977); Hall (1972); and Willis (1929). However, just a few empirical studies on what contractors actually do were identified (see Appendix 1) and these did not seem to articulate sufficiently what contractors actually do in the whole bidding process.

In practice, contractors clearly take account of risks when calculating their bids for construction work. Therefore, analytical risk models could be useful. However, there is no comprehensive study which explains the whole bidding process of contractors, and particularly how risk is taken into account in the process. Without a precise understanding of what contractors actually do when they calculate their bids for construction work, it would be hard to prescribe improvements; it would be hard for the industry to improve on its bidding practices; and it would remain questionable the basis of bidding processes taught in construction schools.

Therefore, the following questions should be addressed:

- What basic activities are involved in bid calculation and to what extent?

- What basic stages and roles are involved in the bidding process?

- How is risk taken into account in the calculation of construction bids?

- To what extent is the bid calculation process systematic in nature? 
Without empirical work explaining what actually happens in practice, which would inform or justify the development of a new approach, the vicious circle seems set to continue. Clearly, our ability to prescribe improvements (such as analytical models) hinges on our ability to describe reality precisely. With the current empirical understanding of what contractors actually do in the whole bidding process, we can safely prescribe very little. Our purpose here is to carry out a comprehensive, inductive and intensive study (see Mintzberg, 1973: 230-231) that captures the whole bidding process and describes particularly the way that contractors take risk into account when pricing work, thus providing a basis for comparing theoretical risk analysis models with the actual practice of risk analysis. The understanding will help to inform future developments to support contractors in their pricing of work.

\section{Specific objectives}

To this end, the specific objectives of the study are:

1. To review analytical approaches proposed by academic researchers for contractor's risk analysis (i.e. theory);

2. To ascertain how contractors actually take account of risk in the bidding process (i.e. practice); and

3. To compare theory with practice to show how the findings can inform future developments to support contractors in their pricing of work.

\section{General research approach}

To achieve the research objectives, three things were necessary. First, identifying and examining analytical approaches proposed in the literature for contractor's risk analysis. This required a comprehensive method for capturing the analytical models, and learning about their propositions and underlying assumptions. Second, ascertaining what contractors actually do about risks in the whole bid-pricing process. This required a comprehensive method for capturing pricing activities, observing what contractors do when they put together a price, and learning about what features they take account of, including the extent to which they apportion risk and the mechanisms that they use for building up their contingencies. Third, comparing results from objectives one and two in order to identify potential areas of significant difference, and make recommendations that will inform future developments. 


\section{Objective \#1: Review of analytical risk models}

The research method for achieving the first objective comprised of an examination of construction management journals, each from their first issue to articles in press (as at May 2008). The purpose was first to take account of all papers on risk that were published in them; and second, to log papers containing proposals for contractor's risk analysis at the tender stage. This helped to learn about the underlying assumptions of the analytical propositions. A paper by Chau (1997) on "The ranking of construction management journals" provided a basic idea of journals in the field. The remaining papers were identified through a rigorous internet search which was followed by another search through a snowballing approach, namely references in papers identified earlier. A comprehensive table of the risk models identified can be found in Laryea and Hughes (2008). Altogether, 67 analytical approaches for contractor's risk analysis were identified (starting from a probabilistic model by Gates, 1971 for quantifying contingencies for bidding mistakes; uncertainties; and variations in monetary terms) and the frequency of publication proved to be increasing: five (5) in 1970s; 11 in 1980s; 24 in 1990s; and 25 in 2000s (so far).

Analytical risk models may be useful. However, several studies of contractors provide evidence and reasons why contractors rarely use the analytical risk models that have proliferated in the literature. In separate research studies involving more than 30 contractors each, Akintoye and MacLeod (1997) and Ahmed et al. (2002) identified eight problems contractors face when confronted with project risk analysis models. Smith and Bohn (1999) criticized risk models for their complexity of analysis and other shortcomings. Their interviews with 12 US contractors showed that contractors often consider market competition as an overriding concern when pricing work, but most analytical risk models hardly address this.

Most of the $60+$ analytical risk models for contractors examined and classified in (authors, 2008) were hardly derived from the kind of information commonly used in practice, apparently. First, they were found to be mainly analytically-derived models. They are based essentially on the mathematical modeling ability of the authors rather than the exigencies of actual bidding practice. Not to mention the sophistication involved, the propositions hardly incorporate the reality that market premium may, in fact, wipe risk premium (see Smith and Bohn, 1999: 106) especially as estimators 
deal with costs whereas Directors deal with premiums. Thus, most analytical risk models did not seem sensitive to the commercial exigencies of bidding practice. Second, most analytical models prescribe a three-step process for approaching risk in the bidding process namely: risk identification; risk assessment (i.e. risk analysis and evaluation); and risk response (i.e. contingency allocation). The classical proposition in most analytical approaches for example, Tah et al. (1993) and Paek et al. (1993) is that based on the evaluated risk value of a project, a risk premium should be included in the bid price to cover risks. However, contractors studied by Smith and Bohn (1999) indicated that in reality they try to avoid inflating their bid prices with risk allowances in order to beat competition and win work. In fact, an ethnographic study of seven tendered projects by Rooke et al. (2004: 658-9) showed that contractors strategize to win the work first and then use mechanisms like claims to recover the cost of risk. Thus, contractors may be adept at dealing with risk, although authors like Al-Bahar and Crandall (1990), Tah and Carr (2000) and Zeng et al. (2007) assume that the intuitive and experiential-based approach used by most contractors when dealing with risk does not form an adequate professional and objective basis for serious project management decisions. Third, no comprehensive study was found in the literature that captures the whole bidding process of contractors; describes how risk is taken into account throughout the process; and shows that pricing is indeed systematic in nature. To this end, systematic models proposed to help contractors in their pricing of work and risk may have no justifiable empirical basis.

\section{Objective \#2: Case studies on bidding process of contractors}

\section{Research design}

The main issues considered in formulating the research design were the nature of the question asked, the unit of analysis, validity of the research findings and how others have approached similar research problems. Most studies in construction management seem to be based on the routine questionnaire and interview surveys. Here, however, the unit of analysis was an entire tender process, i.e. from start (receipt of tender document at the office) to finish (when the bid was ready to submit). The research question was: how do contractors take account of risk when calculating their bids for construction work? In the first place, this required a comprehensive, intensive and inductive strategy for capturing pricing activities, observing what contractors do when 
they put together a price, and learning about what features they take account of, including the extent to which they apportion risk and the mechanisms that they use for building up their contingencies. Clearly, the research required to find answers to these questions needed to be designed to capture what contractors do, rather than merely asking questions based on what the literature reports.

The nature of the question asked required a method that gives a high degree of ecological validity of the research findings (Gill and Johnson, 2002). Hence, a twostage research approach was formulated to help explore deeply into how contractors calculate prices for their bids for construction work, and how risk is taken into account. The first stage of the research project was to carry out a preliminary investigation on some national contractors to gain an initial understanding of their actual bid-pricing practices; review queries developed during the literature review; and identify themes to help in formulating an appropriate research design for the second stage of the research project. The first stage, which involved documentary analyses and in-depth interviews with five UK contractors, was reported in Laryea and Hughes (2008). Therefore, here we focus on the second stage of the research project which was to observe examples of tender preparation in practice to see pricing strategies working at the operational level. Due to a similarity in the nature of the question asked, the approach used for conducting this study was informed by the one used by Mintzberg (1973: 221-229) to investigate what managers actually do.

Using participant observation, interview and documentary analysis, two live cases of the whole bidding process were shadowed in the offices of two of the top $20 \mathrm{UK}$ civil engineering contractors (Hansford, 2008), hereafter referred to as Gamma and Delta. The time spent in Gamma and Delta doing participant observation was six and seven weeks respectively. In both cases, working hours was 0800-1730 hours (including one-hour of break time). The tender period in Gamma started on 03 July 2008 and ended on 13 August 2008 instead of the originally stated 06 August. The reason was to allow bidders more time to incorporate changes introduced in the original tender documents. In Delta, the tender period was 01 September to 17 October 2008 instead of the originally stated end date of 17 September. Here, the extension was caused by a change in the procurement method (i.e. from a design-build to build-only scheme) and changes in the original tender documents. 
Clearly, bidding processes are unique and should be contextualized. The average turnover of the firms is $£ 543 \mathrm{~m}$, and their average workforce of 2466 people comprises of both office and site staff. The case studies involved a close observation of every aspect of putting together a bid. The project in Gamma comprised major infrastructure works proposed to enable a wide area of marsh land to be used for residential and commercial property development for a Local County Council in England. This was to be executed as a Guaranteed Maximum Fixed Price (GMFP) contract. The project in Delta comprised of proposed infrastructure works for a railway terminal in England comprising of platform works, a footbridge, track works, ole works and signaling works. This was to be executed as a Fixed Price contract.

Difficulties were experienced with negotiating access. For example, the director in charge of estimating in one firm emailed the following response: “...I'm afraid that much of the detail we think you are likely to need will be too commercially sensitive for us to grant your request or release to you as this is effectively into the public domain." In short, access negotiation was difficult. The firms that agreed mainly did so because of the importance and influence of the gatekeepers used to negotiate access, the academic purpose of the study, and the written assurances of confidentiality and anonymity in reporting the study.

Engaging with the bid teams, and assisting them throughout the bidding process, helped to obtain a chronological record of basically everything involved in preparing a bid. Data was collected using the researcher's own field notebook (see Appendix 2 for a demonstration of how this was done); diaries given to some members of the bid team to fill in for each day's work; and voice recordings in some cases. Apart from asking direct questions to clarify observations, several interviews were conducted with directors and others involved in the bidding process from an operational, market, and policy perspective. Content analysis was used to interrogate the interview data, this was interpreted to support some of the theory developed from observations.

The chronology record noted basic activities observed in the firms and their extent, as was done in the live observational study of five US chief executives, each over a oneweek period, by Mintzberg (1973: 235) between 1967-8. Most observations here were quite straightforward to categorize and code, but a few were more difficult particularly because of their overlapping features. Bidding activities were operationalized as: calculations (start to finish of all times spent on resourcing, 
pricing, take off, etc); correspondence (start to finish of all times spent giving attention to incoming and outgoing post, email, phone calls); and conversations (start to finish of all times spent on unscheduled meetings, and informal discussions about the bid by the bid team members); documents (time spent studying tender documents); meeting (formal, scheduled discussions about the bid); deskwork (writing of letters, enquiries, tender notes, administrative work, queries, etc), travel (travel time to attend meetings such as site visit or client interview) and off (holidays or time off by a member of the bid team). It was fairly straightforward to sort the data in the chronology record using MS Excel spreadsheet, code it according to the categories described, tally activity durations under each category, and then estimate each activity category as a proportion of the tender period (see Tables 1 and 2). Relevant documents used in the bidding process were also collected and analyzed for example, risk schedules, meeting agenda and minutes, and commercial review reports.

\section{Analysis of the chronology record of observations in Gamma and Delta}

The chronology record (analyzed in Tables 1 and 2) captured basic activities of the bidding processes at Gamma and Delta and their extent.

\section{Gamma case study}

$<$ TABLE $1>$ NEARH HERE

Table 1 shows that the greatest part of the tender period in Gamma was spent on deskwork activities (39\%). This is followed in magnitude by off-days $(20 \%)$, meetings $(13 \%)$, calculations $(12 \%)$, study of documents $(7 \%)$, conversations $(5 \%)$, correspondence $(3 \%)$, and travel $(2 \%)$ respectively. Although the 6 -week tender period was approximately 288 hours, the total combined work on the tender lasted 307 hours, i.e. a difference of 19 hours. This shows some activity overlaps. The analysis of the chronology record showed a total of 17 meetings lasting 41.32 hours, 61 conversations lasting 15.7 hours, 38 different times of calculations lasting 36.32 hours, 11 members if the bid team, at least 363 phone calls and 282 external incoming and outgoing emails, 90 tender query responses, 9 tender addenda, 6.39 hours of studying over 571 pages of drawings and specifications, 20 Gamma queries to consultants, 55 subcontract enquiries, and 22 supply enquiries. More than $50 \%$ of the 90 TQ responses, which had major works scope implications, were received in the final two weeks of the tender process, which had to be extended because of these 
changes. Altogether, at least 313 major bidding activities were recorded and analyzed. The bill of quantities contained 1053 items needed to be priced. The commercial review highlighted 105 clauses in the ICE conditions of contract $7^{\text {th }}$ Edition that had been amended by the client. Two estimators worked on the bid $78 \%$ and $22 \%$ of tender period respectively due to scheduling of holidays. Subcontract quotations were received between 2-5 weeks. Supply quotations were received relatively much earlier: 1-2 weeks. The consultants took an average of four days to reply queries and most query responses introduced changes that affected the bid team's work. Clearly, this sporadic nature of the bidding process hardly seems to model the kind of systematic or rational behaviour most analytical models assume.

The main personnel involved in preparing the bid were: Bid Manager, Estimator and Planner. The Bid Manager coordinated all activities involved in putting together the tender submission, in the format required by the client. He worked throughout the tender period. Two estimators (EI and EII) worked on the bid mainly because of their availability resulting from annual holiday. EI worked $68 \%$ of the tender period (i.e. 21/31 days). EII took over from EI from 2008-07-25 to 2008-08-11. Two of the days overlapped to enable a smooth estimating handover. Estimator II worked $22 \%$ of the tender period ( $7 / 31$ days). No estimating duties were performed on $10 \%$ of the tender period, i.e. 3 days (28-30 July) because both estimators were on holiday. In the final three days, EI finished off the tender, having returned from his holiday. Planners: three planners (PI, PII, and PIII) were involved in preparing the tender programme. The programme was put together in $71 \%$ of the tender period ( 22 days). PI worked for $55 \%$ (17 days) of the tender period. PII and PIII worked for 13\% (4 days) and 3\% (one day) of the time respectively. No planning work was done on $21 \%$ of the tender period ( 9 days) because of holidays and work on other bids.

Three major meetings were used to process the bid submission, i.e. 'start-up', 'midtender review' and 'final tender review' meetings. A commercial analysis of the proposed conditions of contract was carried out by the Commercial Manager. 105 amended clauses were described as 'onerous' and thus requiring review by the client. One reason was to avoid pricing such risks to avoid inflating the tender price. Gamma also thought the client was in a better position to own those commercial risks because of their low probability, high impact nature. Clear assumptions were also stated in areas where adequate specifications were not given for bill items in order to deal with 
risk. The main risks of concern were: commercial risk arising out of the proposed conditions of contract and risks associated with the ecological and archaeological works, programme and weather, and guaranteeing the price and quantities. A risk schedule was prepared and priced. However, most risks were included in the bid as qualifications to the tender programme and price. The description from EII (below) revealed two main types of unsystematic risk that may be priced in contractors' bids namely: 'identified' and 'residual' risk.

“...If you can't do anything about a risk, that is the residual risk, that is often hard to quantify. Some of the risks you can do something to mitigate them - by providing a standby crane for example. These we call identified risks. So those ones, we actually price for them. The residual risk - you have to assess whether it is high, medium or low and whether or not that risk could happen, and the likely cost, the minimum cost, and the maximum cost. At the end of the day you come up with the cost of all the risks, and people will say 'it's too much.' So you devise ways of mitigating those you can. One way is to qualify your tender depending on the client. Some will accept, and some won't..."

Thus, identified risks will normally be included in a bid price and programme. But any residual risk will be left to management, at the adjudication stage, to take a commercial view on the level of risk allowance that is appropriate to price in the bid. Here, a total allowance of $£ 220,000$ was priced initially for eight residual risks. However, the figure was reduced to $£ 120,000$ at the final tender review to enhance competitiveness. Thus, given a risk allowance of $£ 120,000$ for the $£ 6.5 \mathrm{~m}$ project, it implies a risk margin of $1.8 \%$ in the bid. The tender period lasted for 31 days; it was 25 days originally but was extended because of several changes introduced.

\section{Delta case study}

\section{$<$ TABLE $2>$ NEARH HERE}

Table 2 shows that, here too, the greatest part of the tender period was spent on deskwork activities (25\%). This is followed in magnitude by calculations (24\%), study of documents (19\%), meetings (15\%), conversations (9\%), off-days (4\%), travel $(1 \%)$, and correspondence $(2 \%)$ respectively. The chronology record showed that members of the bid team had to process approximately 273 incoming and outgoing phone calls, 124 internal and external emails, 958 bill items to be priced, 1090 pages of tender documents, 23 tender query responses, 2 tender addenda, 31 subcontract enquiries, and 14 supply enquiries. The project was intended to be design-build initially but the client changed their mind in favor of a build-only arrangement. The total combined hours of work on the bid was 363 hours. Subcontract quotes were 
received in an average of 16 days. Supply quotes were received much earlier, i.e. in an average of 5 days. Six major meetings took place. These lasted a total of 54.43 hours. 12 people made up the bid team including the Bid Manager, Estimator, Planner, commercial manager, project manager, ops support, tender administrator and enquiries, SQE, and quantities take off. However, the main people involved, and their periods of engagement in the seven-week tender period are Bid Manager (97\%), Estimator (86\%), and Planner (94\%) respectively. The Bid Manager coordinated all activities involved in the tender process, studied and helped to understand the scope of works, and priced risks. The Planner produced the programme of works. The Estimator priced the bill of quantities using quotations received from the supply and subcontract enquiries. The required elements of the tender submission itself (price, quality, and programme) were put together by the BM with assistance from an administrative staff. Here too, three major meetings used to process the bid submission were the 'tender launch', 'mid-tender review' and 'final tender review' meetings. The tender process was originally scheduled to end in September but this was extended because of a change in the method of procurement and changes in the tender documents. A commercial analysis of the proposed conditions of contract was carried out by the commercial department. This identified 15 amended clauses as 'risky' and requiring a review by the client. The main risks were identified as programme, design and the tight timescales available for delivering the project. In relation to these risks, a formal risk schedule was prepared and priced.

Given the project value of $£ 7.5 \mathrm{~m}$; and the 'risk pot' of $£ 120,850$, it follows that risk margin in the bid was $1.6 \%$. However, this could be slightly higher in other cases. A documentary analysis of previous tenders for 24 projects of value between $£ 1.5$ and $£ 13.8 \mathrm{~m}$ was carried out. The data was captured from the 'tender book' produced in the process of building up a price for each project. The analysis showed that 24 projects with average value of $£ 7.7 \mathrm{~m}$ priced between 2005 and 2008 had an average risk allowance of $2 \%$ in the bids. The conditions of contract for the 24 projects were similar. But given potentially different levels of competition involved in each case, this analysis may be viewed as an approximate estimate of risk apportionment in bids. Here too, the risk allowance seemed to cover 'exceptional' risk, as explained below by the Technical Services Director based on his 23 years of experience. 
“...There is a certain amount of risk that is automatically priced in the bid, based on the documents given. This is a normal risk allowance. However, the estimate often does not include an allowance for exceptional risk because they cannot be quantified and priced..."

Thus, two types of internal risk may be priced in bids: 'normal' risk (which is taken into account by estimators and planners) and 'exceptional' risk (which directors will take a view on based on market and firm circumstances). Most of the commercial risks were taken into account using qualifications, assumptions, and clarifications in the tender programme and price. Based on 25 years' experience, the Chief Executive of Delta classified proposed projects into good jobs (25\%), normal jobs (50\%) and risky jobs (25\%). He explained that generally, risk influences pricing levels by $1-3 \%$ in most normal jobs. For risky jobs, risk could be up to $7.5 \%$, and it could be $0 \%$ in good jobs where potential opportunities often balance out the risk.

\section{Risk accountability in bids (Tier 1-3)}

The close observation, interviews and documentary analyses of the work of contractors revealed that there may be three tiers of risk apportionment in a bid. The first level of risk apportionment in a bid (Tier 1) occurs at the individual level of the estimator (and programme planner). When estimators are calculating quantities and unit rates, they subjectively compensate for inaccuracies and errors, using experience and gut-feel, by adjusting the estimate until an intuitive satisfaction is felt about its adequacy (see Smith and Bohn, 1999: 106 where the authors explained that "In reality contractors tend to 'buffer' their bids when they feel uncertain about the cost of an individual item"). Here, the risk apportionment may depend on the experience and skill of the estimator (and planner). Sometimes, the risk component may be included so smoothly that even the estimator does not realize it is being included. The second level of risk apportionment in a bid (Tier 2) occurs at the level of the bid team where they think through the actual construction phase of the project and include a price for any identified or operational risks. Here, the risk apportionment may depend on the level of expertise in the contractor's estimating department. The third level of risk apportionment in a bid (Tier 3) occurs at the final stage of the tender process where a firm's management ultimately decides on the allocation of a residual risk allowance in a bid, sometimes based on a risk value calculated with the help of a risk register and probability-impact matrix. Here, they take into account market conditions and firm's 
particular circumstances and the risk apportionment may depend on the experience of a firm's management and their attitude towards risk.

\section{Objective \#3: Comparison of theory and practice}

Five points are discussed. First, on the comparison of analytical risk models with what contractors actually do, it was found that most models prescribe the addition of a contingency allowance in bids for risk, based on a calculated risk value (see for example, Tah et al. 1993; and Zeng et al. 2007). However, particularly in competitive markets and recessionary periods, contractors often cannot afford to price risk mainly because of the fear of losing work (Smith and Bohn, 1999: 107). Here, both Gamma and Delta tried to use clever strategies and tactics in their bid proposals to insure against commercial and operational risks. In fact, both contractors carried out a commercial analysis of the proposed conditions of contract and decided on the best way to approach risks: either to avoid bidding at all or to qualify (or clarify) the commercial risks as part of the tender submission for post-tender negotiations. In relation to operational risks, both contractors stated clear assumptions upon which their offer (tender programme and price) was based. Therefore, analytical models prescribe contingency allocation whereas contractors here managed risk mostly through contractual rather than price mechanisms, to reflect commercial imperatives.

Second, the main bidding activities of contractors were categorized and their extent estimated as deskwork (32\%), calculations (19\%), meetings (14\%), study of tender documents $(13 \%)$, off-days $(11 \%)$, conversations $(7 \%)$, correspondence $(3 \%)$ and travel (1\%). This approximation was based on the average of two chronology records analyzed from 670 hours of direct participant observation in Gamma and Delta (see Tables 1 and 2). Table 3 shows details of the main bid preparation activities observed in Gamma and Delta and three stages of the whole bidding process of contractors.

\section{$<$ TABLE $3>$ NEAR HERE}

The estimating activities did not appear to follow the typical S-curve behaviour illustrated in The PMBOK Guide to the Project Management Body of Knowledge. Here, the pattern of estimators' activity was loaded at the beginning (with the tender documents being studied to gain an understanding of the scope of works in order to prepare supply and subcontract quotes and price the job well), slowed in the middle 
(with quotations awaited), and loaded towards the end (with quotations in, addenda, query responses, meetings, and submission time nearing). The typical S-curve behaviour is described as follows (Cioffi, 2005):

"When displayed as a function of time, accumulated efforts or costs of a project usually takes a form described as the S-curve (flatter at the beginning and end, steeper in the middle). The classic S-curve is described as having three parts: a gentle rise, a steep slope, and a gradual path to the asymptote".

However, the pattern of basic activity here appeared steeper at the beginning and end and flatter in the middle. Hence, bidding activities of estimators (see Table 3) may not model the typical S-curve behaviour. An examination of the chronology records from Gamma and Delta showed that although the two tender processes related to projects that were different in nature, the basic activities performed by the bid teams were significantly similar. This showed that bidding practices may be dictated by company practices and not project variables; this should be investigated further.

Third, the risk and price relationship of 0-3\% expressed in most parts of the literature for example, Neufville and King (1991) and Smith and Bohn (1999) was clearly confirmed in Gamma and Delta (1.6\% and 1.8\% respectively). The analysis of past tenders in Delta showed that an average of $2 \%$ risk margin was included in 24 bids of average value $£ 7.7 \mathrm{~m}$ priced between 2005 and 2008. This risk allowance seemed to cover mainly the residual risk (Tier 3 ) of the projects. It did not seem to include allowances for identified risks (Tier 2) and intuitive risk allowances included by the estimator to compensate for estimating inaccuracies and errors in the estimates (Tier 1). Therefore, prior to apportionment of $1-2 \%$ residual risk allowance in some bids by management, identified and intuitive risk allowances may be included in a bid by estimators and planners. Hence, it appeared that the 5-10\% margin that textbooks suggest as risk allowance in contractor bids may ring true in this context.

Fourth, the findings show how risk is priced mostly through contractual rather than price mechanisms, to reflect commercial imperatives at the time of bidding. Contractors were concerned about the risk of getting the tender price wrong. Hence, mechanisms used to deal with risk included a commercial review of the conditions of contract; commercial and planning review sessions by the bid team; and the use of assumptions, qualifications and clarifications in the tender programme and price. Two main risks of concern were commercial and operational risk. Depending on the degree to which the proposed contract conditions were considered 'onerous', the bid teams decided on the best way to approach risks, i.e. either to avoid bidding at all, or 
qualify (or clarify) the risks as part of the tender submission for post-tender negotiations with the client. Operational risk related to the perceived difficulty in carrying out the actual job under physical conditions such as access, location and ground. In relation to these, the contractors stated clear assumptions upon which their offer was based. Thus, it became clear that instead of pricing in risk allowances that will inflate the bid price, and probably cause them to be uncompetitive, strategies and tactics were devised to help offer the best (lowest) price for 'getting a foot in the door' or 'getting to the table' to negotiate risks with the client at the post-tender stage. This was found to be one reason why contractors may not approach risks according to the contingency allocation theory proposed in most analytical risk modeling approaches.

Fifth, risk premiums are often decided by a firm's directors based on the confidence perceived in the explanations of the bid team's work. There was significant difference in the way the two main stages of the tender process (estimating stage and adjudication stage) are approached. This was clarified by one of the chief executives: "The estimating process involves a lot of rational steps, in terms of the way you build up the price. But when it comes to settling the tender, that process is more of a gutfeel or art to know the right prices. Gut-feel is your instincts - is the job right, priced properly? You judge the confidence in the guys who priced it and the way they display it when they come to settle the bid". Thus, as some directors described it, the process that they use to pitch the final tender price, to make it respond well to buyers in the construction market, is intuitive, unsystematic, and a skill that they gain from experience. Hence, establishing the right balance between the related concepts of cost, price and value in bidding is an important commercial exercise for a firm's directors. It is not just a technical exercise. Four main factors considered were commercial risks; operational risks; competition; and desire to win the work. If the directors feel confident of the bid team's work, and want to win a job, they may price for some of the residual risk and assume the rest, which they would hope to manage through opportunities in the construction phase. However, when a job is needed, they may compromise to win it by assuming the residual risk and pricing a lower margin.

\section{Conclusions}

Three main conclusions are drawn. First, formal and analytical risk models prescribe how risk should be incorporated in construction bids. However, a review of $60+$ 
propositions showed that most of them are analytically derived and not informed by any major empirical research on what contractors actually do in practice. No comprehensive study that captures the whole bid-pricing process of contractors; describes how risk is taken into account throughout the bid-pricing process; and shows that pricing is indeed systematic in nature was found. To this end, systematic propositions for contractors were considered to have no justifiable empirical basis. Most models prescribe contingency allocation in bids. However, in practice, contractors tend to approach risk more circumspectly than the models prescribe because of a set of complex, microeconomic factors like the scope of works, forward workload, need-for-work, competition and other exigencies of bidding practice that also affect price. Thus, the contingency allocation theory underpinning most analytical risk models may not be sustainable in practice.

Second, in order to compare the theoretical risk analysis models with the practice of risk analysis, access was negotiated and the whole tender process was shadowed in the offices of two of the top 20 UK civil engineering contractors. The aim here was to explore deeply rather than superficially into what contractors actually do. Hence, the participant observation method used, although exhausting in nature, helped to achieve a high degree of ecological validity of the research findings. Three stages of the bidding process were found and bidding activities were categorized and their extent estimated. The bidding process did not seem to follow any systematic pattern; its activities depended on the prevailing daily circumstances of the bid team. The difficulty in achieving a programmable bidding process was caused by changes to the tender documents, poor quality of tender documents, personnel problems and reliance on the supply chain for information to price the bid. Thus, assumptions of systematic behaviour in bidding practice does not ring true in this context.

Third, three tiers of risk apportionment in bids were identified (Tier 1-3). Tier 1: intuitive risk allowances included in the tender programme and price by estimators and planners to compensate for inaccuracies and errors in estimates; Tier 2: bid teams tend to include an allowance in the bid for the identified risks in a project; and Tier 3: a firm's management decides on the appropriate level of residual risk allowance to include in a bid. Thus, different individuals and teams influence pricing levels at different stages of the bid calculation process. Sometimes, priced risks may be excluded from a bid to enhance the chances of winning a job. The tender adjustments 
for risk may take considerable time to decide but the actual arithmetic involved in reducing or increasing the final price tends to be simpler than the sophisticated prescription of analytical models. Thus, analytical models may be too timeconsuming, too complex and insensitive to the commercial exigencies of bidding practice. Clearly, risk is an important factor in the bid calculation process of contractors, which often takes place in a short time frame and competitive market environment. Perhaps, a simple table of risk factors, which could be for example, location/project-specific, which indicates a scale or factor by which contractors could easily and flexibly adjust an estimate for risk may be handier and even appropriate.

\section{Acknowledgements}

We thank the contractors who allowed this study to take place in their firms. We thank those who helped to negotiate access into the firms. And we thank Tim Carter of Davis Langdon and John Laverty of the Institution of Civil Engineers (ICE South East) for helping us throughout the research project. Comments from anonymous referees who reviewed this work helped to improve the paper significantly.

\section{References}

Ahmed, S.M. Azhar, S. and Ahmad, I. (2002) Evaluation of Florida General Contractor's risk management practices, Journal of Construction Engineering, CIB, 17(1), 4-11.

Akintoye, A. and Fitzgerald, E. (2000) A survey of current cost estimating practices, Construction Management and Economics, 18(2), 161-72.

Akintoye, A. S. and MacLeod, J. M. (1997) Risk analysis and management in construction, International Journal of Project Management, 15(1), 31-38.

Al-Bahar, J. F. and Crandall, K. C. (1990) Systematic risk management approach for construction projects, Journal of Construction Engineering and Management, ASCE, 116(3), 533-546.

Atkinson, D. (2007) How all risk cover works, Construction News, 15.03.2007

Baloi, D. and Price, A. D. F. (2003) Modeling global risk factors affecting construction cost performance, International Journal of Project Management, 21(4), 261-269.

Brook, M. (2004) Estimating and tendering for construction work, 3ed, Boston: Butterworth Heinemann.

Brun, W. Risk perception: main issues, approaches and findings in subjective probability, Eds: Wright, G. and Ayton, P. (1994), London: Wiley. 
Chan, E. H. W. and Au, M. C. Y. (2007) Building contractors' behavioural pattern in pricing weather risks, International Journal of Project Management, 25(6), 615-626.

Chapman, C. B., Ward, S. C. and Bennell, J. A. (2000) Incorporating uncertainty in competitive bidding, International Journal of Project Management, 18, 334-347.

Connolly, J. P. (2006) Discussion of modeling a contractor's markup estimation, Journal of Construction Engineering and Management, 132(6), 657-658

Dalton, M. (1959) Men who manage, New York: Wiley.

Denscombe, M. (2007) The Good Research Guide, 3ed, Maidenhead: Open University Press.

Enterkin, H. and Reynolds, G. (1978) Estimating for builders and surveyors, 2ed, Oxford: Heinemann.

Fischer, D. and Jordan, R. (1996) Security analysis and portfolio management, London: Prentice-Hall.

Gates, M. (1971) Bidding Contingencies and Probabilities, Journal of the Construction Engineering Division, 97, 2, 277-303.

Gill, J. and Johnson, P. (2002) Research Methods for Managers, 3ed. London: Sage

Hall, D.S.M (1972) Elements of estimating, London: B T Batsford.

Hansford, M. (Ed.) (2008) Contractors File, Top 20 Civil Engineering Contractors, New Civil Engineer, Emap Inform, London.

Harrison, S. (1981) Estimating and tendering - some aspects of theory and practice, Estimating information service, The Chartered Institute of Building, ISSN 0308 8073, No.41. 1981.

Hillebrandt, P.M. (1985) Economic Theory and the Construction Industry, 2ed, London: Macmillan.

Hughes, W.P. (1998) Financial protection in the UK building industry: bonds, retentions and guarantees, London: Spon.

Hughes, W. P. and Hillebrandt, P.M. (2003) Construction industry: historical overview and technological change, In: Mokyr, Joel (ed.-in. chief) The Oxford Encyclopaedia of Economic History, Oxford: Oxford University Press, 2003, 1, 504-512.

Kangari, R. and Riggs, L. S. (1989) Construction risk assessment by linguistics, IEEE Transactions on Engineering Management, 36(2), 126-131.

Kwakye, A. A. (1997) Construction project administration in practice, London: Longmann.

Laryea, S. and Hughes, W. (2008) How contractors price risk in bids: theory and practice, Construction Management and Economics, 26: 9, 591-608.

Lipsey, R.G. (1979) An introduction to positive economics, 5ed, London: Weidenfeld and Nicolson.

Liu, M. and Ling, Y.Y. (2005) Modeling a contractor's markup estimation, Journal of Construction Engineering and Management, ASCE, 131(4) 391-399. 
Mintzberg, H. (1973) The Nature of Managerial Work, New York: Harper and Row

Mochtar, K. and Arditi, D. (2001) Pricing strategy in the US Construction industry, Construction Management and Economics 19, 405-415.

Murdoch, J. and Hughes, W. (2008) Construction contracts, 4ed, London: Taylor \& Francis.

Neufville, R. and King, D. (1991) Risk and need-for-work premiums in contractor bidding, Journal of Construction Engineering and Management, 117(4), 659-73.

Paek, J.H., Lee, Y.W. and Ock, J.H. (1993) Pricing construction risk: fuzzy set application, Journal of Construction Engineering and Management ASCE, 109(4), 743-56.

Project Management Institute (2004) A guide to the Project Management Body of Knowledge, (PMBOK Guide) 3ed.

Rooke, J., Seymour, D. and Fellows, R. (2004) Planning for claims: an ethnography of industry culture, Construction Management and Economics 22(6) 655-662.

Runeson, G. and Skitmore, M. (1999) Tendering theory revisited, Construction Management and Economics, 17, 285-296.

Saunders, M.N.K., Lewis, P. and Thornhill, A. (2007) Research methods for business students, $\mathbf{4 e d}$.

Shash, A. A. (1993) Factors considered in tendering decisions by top UK contractors, Construction Management and Economics, 11, 111-118

Shash, A. A (1998) Bidding practices of sub-contractors in Colorado, Journal of Construction Engineering and Management, ASCE, 124(3), 219-225.

Shash, A. A. and Al-Amir, M. (1997) Information technology in contractors' firms in Saudi Arabia, Construction Management and Economics, 15, 187-200.

Shash, A. A and N.H. Abdul-Hadi (1992) Factors affecting a constructor's margin-size decision in Saudi Arabia, Construction Management and Economics, 10, 415-429.

Skitmore, R.M., Stradling, S.G. and Tuohy, A.P. (1989) Project management under uncertainty, Construction Management and Economics, 7(2), 103-113.

Skitmore, M. and Wilcock, J. (1994) Estimating processes of smaller builders, Construction Management and Economics, 12, 139-154.

Skitmore, M., Runeson, G. and Chang, X. (2006) Construction price formation: full-cost pricing or neoclassical microeconomic theory? Construction Management and Economics, 24, 773-783.

Smith, G. R. and Bohn, M. C. (1999) Small to medium contractor contingency and assumption of risk, Journal of Construction Engineering and Management, ASCE, 125(2), 101-108.

Smith, R. C (1986) Estimating and tendering for building work, Longman: London. 
Tah, J.H.M., Thorpe, A. and McCaffer, R. (1993) Contractor project risks contingency allocation using linguistic approximation, Journal of Computing Systems in Engineering, 4(2-3), 281-293.

Tah, J.H.M., Thorpe, A. and McCaffer, R. (1994) A survey of indirect cost estimating in practice, Construction Management and Economics, 12(31), 31-36.

Wainwright, W. H. and Wood, A. A. B. (1977) Practical builders' estimating, London: Hutchinson \& Co.

Wilkinson, D. and Birmingham, P. (2003) Using research instruments, London: Routledge Falmer.

Williams, T. M. (1996) The two-dimensionality of project risk, International Journal of Project Management, 14(3), 185-186.

Willis, A.J. (1929) Some notes on taking off quantities. London: Architectural press.

Wong, J. T. Y. and Hui, E. C. M. (2006) Construction project risks: further considerations for constructors' pricing in Hong Kong, Construction Management and Engineering, 24, 425-438.

Wood, R. D (1982) Principles of estimating, 6ed. London: Estates Gazzette.

Wright, G. and Ayton, P. (ed.) (1994) Subjective probability, Chichester: John Wiley

Zeng, J., An, M. and Smith, N. J. (2007) Application of a fuzzy based decision making methodology to construction project risk assessment, International Journal of Project Management, 25, 6, 589-600. 


\section{APPENDICES}

Appendix 1 Empirical studies in journals on how contractors price their work

\begin{tabular}{|c|c|c|c|c|c|c|c|c|c|}
\hline Authors & Year & Journal & Vol. & Issue & Pages & $\begin{array}{l}\text { Aspect(s) of } \\
\text { bid pricing }\end{array}$ & $\begin{array}{l}\text { Research } \\
\text { method }\end{array}$ & $\begin{array}{l}\text { Data } \\
\text { points }\end{array}$ & Country \\
\hline Uher & 1991 & CME & 9 & 6 & $495-508$ & Risks & Q. Survey & 47 & Australia \\
\hline $\begin{array}{l}\text { Neufville and } \\
\text { King }\end{array}$ & 1991 & JCME & 117 & 4 & $659-673$ & $\begin{array}{l}\text { Risk and } \\
\text { need for } \\
\text { work }\end{array}$ & $\begin{array}{l}\text { Experiment } \\
\text { and interview }\end{array}$ & 30 & US \\
\hline $\begin{array}{l}\text { Mak and } \\
\text { Raftery }\end{array}$ & 1992 & CME & 10 & 4 & $303-320$ & Errors & Experiment & 62 & UK \\
\hline $\begin{array}{l}\text { Shash and } \\
\text { Abdul-Hadi }\end{array}$ & 1992 & CME & 10 & 5 & $415-429$ & Markup & Q. Survey & 71 & $\begin{array}{l}\text { Saudi } \\
\text { Arabia }\end{array}$ \\
\hline Shash & 1993 & CME & 11 & 2 & $111-118$ & $\begin{array}{l}\text { tendering / } \\
\text { markup }\end{array}$ & Q. Survey & 85 & UK \\
\hline Kodikara et al. & 1993 & $\mathrm{CME}$ & 11 & 4 & $261-269$ & BQ & Interview & 8 & Sri Lanka \\
\hline $\begin{array}{l}\text { Kodikara and } \\
\text { McCaffer }\end{array}$ & 1993 & CME & 11 & 5 & $341-346$ & $\begin{array}{l}\text { Estimating } \\
\text { data }\end{array}$ & Interview & 10 & Sri Lanka \\
\hline Tah et al. & 1994 & CME & 12 & 1 & $31-36$ & $\begin{array}{l}\text { Indirect } \\
\text { costs }\end{array}$ & Q. \& I. Survey & 7 & UK \\
\hline $\begin{array}{l}\text { Skitmore and } \\
\text { Wilcock }\end{array}$ & 1994 & CME & 12 & 2 & $139-154$ & Item pricing & Q. Survey & 8 & UK \\
\hline $\begin{array}{l}\text { Edwards and } \\
\text { Edwards }\end{array}$ & 1995 & CME & 13 & 6 & $485-491$ & Services & Documents & 15 & Australia \\
\hline Ming et al. & 1996 & CME & 14 & 3 & $253-264$ & Profit & Documents & 221 & Australia \\
\hline Uher & 1996 & ECAM & 3 & $1 / 2$ & $83-95$ & $\begin{array}{l}\text { Estimating } \\
\text { practices }\end{array}$ & Q. \& I. Survey & 10 & Australia \\
\hline $\begin{array}{l}\text { Shash and Al- } \\
\text { Amir }\end{array}$ & 1997 & CME & 15 & 2 & $187-200$ & $\begin{array}{l}\text { Processing, } \\
\text { use of IT }\end{array}$ & Q. Survey & 93 & $\begin{array}{l}\text { Saudi } \\
\text { Arabia }\end{array}$ \\
\hline Bajaj et al. & 1997 & $\mathrm{CME}$ & 15 & 4 & $363-369$ & Risks & Q Survey & 19 & Australia \\
\hline Shash & 1998 & CME & 124 & 3 & $219-225$ & $\begin{array}{l}\text { Bidding } \\
\text { practices }\end{array}$ & Q. Survey & 30 & US \\
\hline Shash & 1998 & JCEM & 124 & 2 & 101-106 & $\begin{array}{l}\text { Pricing } \\
\text { decisions }\end{array}$ & Q. Survey & 30 & US \\
\hline Ray et al. & 1999 & $\mathrm{CME}$ & 17 & 2 & $139-153$ & Ethics & Q. Survey & 60 & Australia \\
\hline Smith \& Bohn & 1999 & JCEM & 125 & 2 & $101-108$ & Risks & Interview & 12 & US \\
\hline Akintoye & 2000 & CME & 18 & 1 & $77-89$ & Estimating & Survey & 84 & UK \\
\hline $\begin{array}{l}\text { Akintoye and } \\
\text { Fitzgerald }\end{array}$ & 2000 & CME & 18 & 2 & $161-172$ & $\begin{array}{l}\text { Cost } \\
\text { estimating }\end{array}$ & Q. Survey & 84 & UK \\
\hline $\begin{array}{l}\text { Mochtar and } \\
\text { Arditi }\end{array}$ & 2001 & CME & 19 & 4 & $405-415$ & $\begin{array}{l}\text { Pricing } \\
\text { strategy }\end{array}$ & Survey & 400 & US \\
\hline Asaaf et al. & 2001 & IJPM & 19 & 5 & 295-303 & Risks & Q. Survey & 38 & Hong Kong \\
\hline Wong and Hui & 2006 & $\mathrm{CME}$ & 24 & 4 & $425-438$ & Risks & Q. Survey & 38 & Hong Kong \\
\hline Chan and $\mathrm{Au}$ & 2007 & IJPM & 25 & 6 & $615-626$ & $\begin{array}{l}\text { Weather } \\
\text { risks }\end{array}$ & Q. Survey & 60 & Hong Kong \\
\hline
\end{tabular}

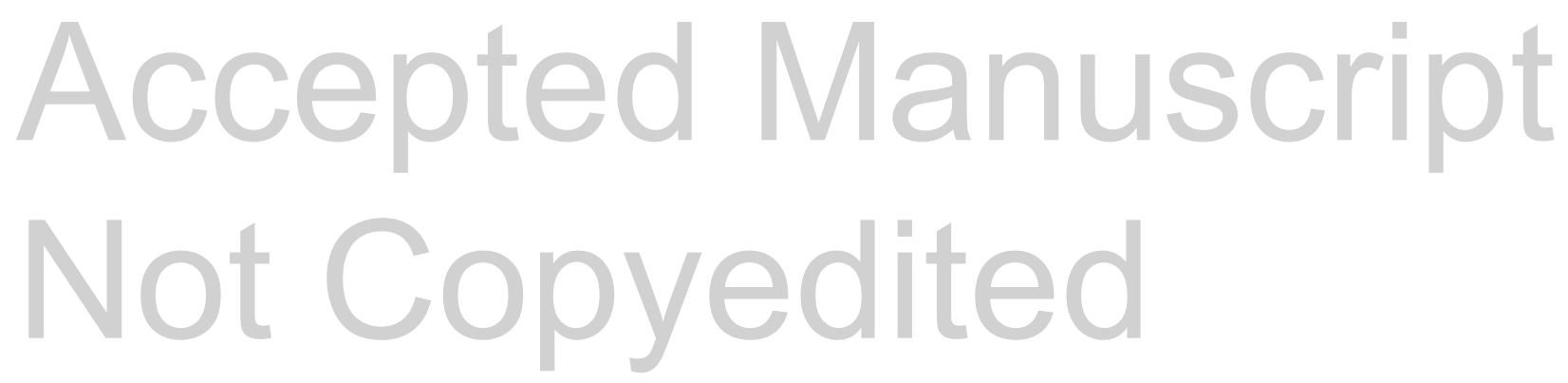


Appendix 2 Chronology record of one estimator's work on D30: 2008-08-12

\begin{tabular}{|c|c|c|c|c|}
\hline Ref & Time & Code & Activity description & Location \\
\hline $30 \mathrm{~A}$ & $\begin{array}{l}0800- \\
0933\end{array}$ & DW & $\begin{array}{l}\text { Estimator goes through all the tender adds/omits arising } \\
\text { from final tender review meeting }\end{array}$ & $\begin{array}{l}\text { Estimator's } \\
\text { office }\end{array}$ \\
\hline $30 \mathrm{~B}$ & $\begin{array}{l}0933- \\
1100\end{array}$ & $\mathrm{CA}$ & $\begin{array}{l}\text { Estimator making adjustments from review meeting and } \\
\text { late issued amendments from client }\end{array}$ & Area office \\
\hline $30 \mathrm{C}$ & 1101 & $\mathrm{CE}$ & $\begin{array}{l}\text { Estimator reads TQ } 82 \text { response just received in relation to } \\
\text { Commitments register, and a further response to TQ20 re } \\
\text { rail possession dates }\end{array}$ & Area office \\
\hline $30 \mathrm{C}$ & $\begin{array}{l}1101- \\
1107\end{array}$ & $\mathrm{D}$ & $\begin{array}{l}\text { Estimator reads through quickly to determine whether } \\
\text { prices will be affected or qualified. }\end{array}$ & $\begin{array}{l}\text { Estimator's } \\
\text { office }\end{array}$ \\
\hline $30 \mathrm{D}$ & $\begin{array}{l}1108- \\
1149\end{array}$ & $\mathrm{CN}$ & $\begin{array}{l}\text { Estimator discusses programme revisions with planner to } \\
\text { understand how it affects prices. }\end{array}$ & $\begin{array}{l}\text { Estimator's } \\
\text { office }\end{array}$ \\
\hline $30 \mathrm{E}$ & $\begin{array}{l}1150- \\
1206\end{array}$ & $\mathrm{CN}$ & $\begin{array}{l}\text { Bid manager, estimator, and tender manager discuss the } \\
\text { changes being made in the tender figures. Estimator: "The } \\
\text { job itself is a simple straightforward job but it's been made } \\
\text { complicated by all these ecological and archaeological } \\
\text { works and how the tender process has been handled." BM: } \\
\text { "I think whoever wins it will depend on the amount of } \\
\text { qualifications in the tender" }\end{array}$ & $\begin{array}{l}\text { Bid } \\
\text { manager's } \\
\text { office }\end{array}$ \\
\hline $30 \mathrm{~F}$ & $\begin{array}{l}1206- \\
1402\end{array}$ & $\mathrm{CN}$ & $\begin{array}{l}\text { Estimator back in his office. Cross-checking and } \\
\text { transferring directs bill of quantities to excel }\end{array}$ & $\begin{array}{l}\text { Estimator's } \\
\text { office }\end{array}$ \\
\hline $30 \mathrm{G}$ & $\begin{array}{l}1403- \\
1613\end{array}$ & $\mathrm{CA}$ & $\begin{array}{l}\text { Cross-checking and transferring indirects bill of quantities } \\
\text { to excel }\end{array}$ & $\begin{array}{l}\text { Estimator's } \\
\text { office }\end{array}$ \\
\hline $30 \mathrm{H}$ & $\begin{array}{l}1613- \\
1630\end{array}$ & $\mathrm{CN}$ & $\begin{array}{l}\text { Estimator phones drainage subcontractor to notify him of } \\
\text { some new changes and find out whether his prices change } \\
\text { as a result. Drainage subcontractor informs him that he } \\
\text { learned about it from one of the other tenderers but } \\
\text { quotation is still fine to use }\end{array}$ & $\begin{array}{l}\text { Estimator's } \\
\text { office }\end{array}$ \\
\hline $30 \mathrm{~J}$ & $\begin{array}{l}1630- \\
1715\end{array}$ & $\mathrm{CA}$ & Calculating savings for use of alternative materials & $\begin{array}{l}\text { Estimator's } \\
\text { office }\end{array}$ \\
\hline $30 \mathrm{~K}$ & $\begin{array}{l}1715- \\
1800\end{array}$ & DW & $\begin{array}{l}\text { Final check on documents and file/number ready for } \\
\text { printing out. Shuts down computer }\end{array}$ & $\begin{array}{l}\text { Estimator's } \\
\text { office }\end{array}$ \\
\hline
\end{tabular}

\section{Accepted Manuscript Not Copyedited}




\section{TABLES}

Table 1 Analysis of the chronology record of activity observations in Gamma

\begin{tabular}{|c|c|c|c|c|c|c|c|c|c|}
\hline Activities & Calc. & Conv. & Corr. & Deskwork & Docs. & Mtg. & Off & Travel & Total \\
\hline Time (hours) & 36.32 & 15.7 & 7.9 & 120.12 & 20.6 & 41.32 & 60.03 & 4.92 & 306.91 \\
\hline Percent (\%) & 11.83 & 5.12 & 2.57 & 39.14 & 6.71 & 13.46 & 19.56 & 1.60 & $100 \%$ \\
\hline
\end{tabular}

Table 2 Analysis of the chronology record of observations in Delta

\begin{tabular}{|c|c|c|c|c|c|c|c|c|c|}
\hline Activities & Calc. & Conv. & Corr. & Deskwork & Docs. & Mtg. & Off & Travel & Total \\
\hline Time (hrs) & 88.42 & 33.50 & 8.55 & 91.97 & 68.88 & 54.43 & 15.25 & 2.38 & 363.38 \\
\hline Percent (\%) & 24.33 & 9.22 & 2.35 & 25.31 & 18.96 & 14.98 & 4.20 & 0.66 & $100 \%$ \\
\hline
\end{tabular}

Table 3 Bidding process stages and activities

\begin{tabular}{|c|c|c|}
\hline INITIAL STAGE & MIDDLE STAGE & FINAL STAGE \\
\hline Receipt of tender documents & $\begin{array}{l}\text { Subcontract and supply work } \\
\text { packages enquiries } \\
\text { (identification and dispatch) }\end{array}$ & Updating of bill prices from quotations \\
\hline $\begin{array}{l}\text { Logging in of new tender information } \\
\text { (approximate value - determines the team } \\
\text { size) }\end{array}$ & $\begin{array}{l}\text { Resourcing and pricing of bill } \\
\text { items (with allowances for risk } \\
\text { included in estimates) }\end{array}$ & $\begin{array}{l}\text { Final tender review - commercial and } \\
\text { planning/programme (risk may be included } \\
\text { in final tender programme and price, then } \\
\text { qualifications - what the price is based on. } \\
\text { Programme - weather risk, LAD risk, } \\
\text { possessions, sectional completion dates) }\end{array}$ \\
\hline Appointment of tender team & $\begin{array}{l}\text { Mid-term client meeting for } \\
\text { clarifications }\end{array}$ & Tender adjustments (adds/omits) \\
\hline $\begin{array}{l}\text { Preliminary study of tender documents and } \\
\text { checking of documents received }\end{array}$ & $\begin{array}{l}\text { Mid-term tender review (review } \\
\text { of draft programme, pricing } \\
\text { strategy, risk and opportunity) }\end{array}$ & $\begin{array}{l}\text { Submission of tender programme and price } \\
\text { (including qualifications, clarifications, and } \\
\text { tenderer's assumptions for post tender }\end{array}$ \\
\hline
\end{tabular}

programme risk, bid/no-bid conditions interim and final review meetings, tender preparation programme, pricing strategy) Detailed study of tender documentation Commercial review

Site visit

Preliminary programme to assess the risk and feasibility of the client's programme

Pricing of indirect costs Pricing of fixed costs Risk meeting and pricing of the risk schedule led by bid manager

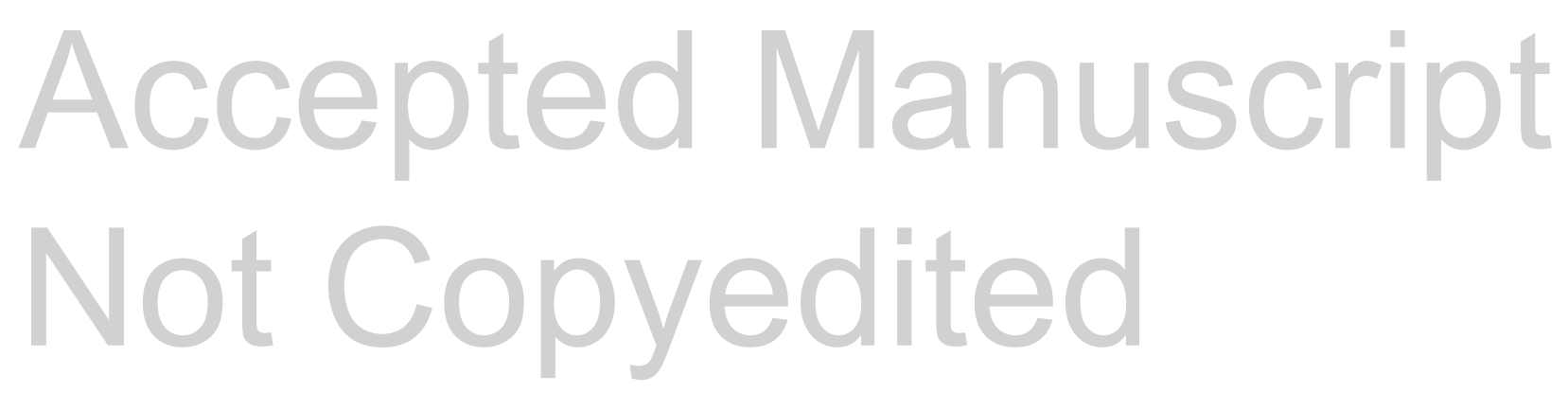

